\title{
Polyethylene Glycol (PEG) Induced Changes in Germination, Seedling Growth and Water Relation Behavior of Wheat (Triticum aestivum L.) Genotypes
}

\author{
Most. Faijunnahar, Abdullahil Baque", Md. Ahsan Habib, H. M. M. Tariq Hossain \\ Department of Agronomy, Sher-e-Bangla Agricultural University, Bangladesh
}

Copyright $\mathrm{C} 2017$ by authors, all rights reserved. Authors agree that this article remains permanently open access under the terms of the Creative Commons Attribution License 4.0 International License

\begin{abstract}
Pre-sowing seed treated with Polyethylene Glycol (PEG) assumed to be a potential priming agent to increase the germination, seedling growth and water relation behavior of grain. With this view, a lab investigation was carried out to find out the effect of various PEG concentrations on the germination, seedling growth and water relation behavior of wheat. Seeds of ESWYT-5, ESWYT -6 and ESWYT-7 wheat genotypes and BARI Gom 28 were pre-soaked in water with $0 \%, 5 \%$, $10 \%, 15 \%$ and $20 \%$ PEG solutions. Results of the study revealed that seed priming enhanced germination, seedling growth and water relation behavior of wheat genotypes. Among four wheat genotypes, ESWYT-5 performed the best regarding germination, seedling growth and water relation behavior where wheat genotypes ESWYT-6 and BARI Gom 28 performed moderately and ESWYT-7 showed consistently poor performance. All the characters showed the best results when wheat seeds treated with $10 \%$ PEG solution compared to nonprime and hydro primed seeds and the value decreased gradually with increasing PEG concentration. These results suggest that seed priming had significant effect to boost the germination, seedling growth and water relation behavior of wheat genotypes.
\end{abstract}

Keywords Germination, Seedling Growth, Water Relation Behavior, Polyethylene Glycol, Osmo Priming and Hydro Priming

\section{Introduction}

Wheat (Triticum aestivum L.), one of the most significant staples food crop, it accounts for about $20 \%$ of the human food supply and is cultivated on approximately 215 million hectors globally WHEAT [1]. Like other living organisms, the creation of defense mechanism under stress condition is a natural phenomenon of the plant, and that is why the yield of crops decreases but helps to enhance the seed quality Quamruzzaman et al. [2]. Despite the some positive impact of stress but it is not suitable for on seed germination, especially for salt and drought stress. And for this reason, seed priming is considered as an effective means to enhance stress tolerance capability of plant under adverse conditions (especially salinity and drought). Seed priming is a new innovative technique by which some physiological changes are gained into target grain with the use of natural and synthetic compounds prior to germination Seed priming is the induction of a particular physiological state in plants by the treatment of natural and synthetic compounds to the seeds before germination. The physiological condition of plants in which plants can faster or better activate defense responses or both is called the primed condition of the plant Beckers and Conrath, [3]. It optimizes seed performance by rapid and uniform germination, healthy and vigorous seedlings growth reaching a physiological condition resulted in faster and better germination and the emergence of different crops Basra et al. [4], Cantliffe [5], Powell et al. [6] and Taylor et al. [7]. Primed seedling can produced normal seedling under stress condition. Carbineau and Come [8] and Ashraf and Foolad [9] reported that, under stress condition primed seedling able to grow normally without any disturbance.

Priming allows some of the metabolic processes essential for germination to occur without germination take place. During priming, seeds are drenched in various priming solutions. Thus the seeds were prevented from absorbing enough water for radical protrusion and retarding the seeds in the lag phase Taylor [7]. Seed priming has been commonly used to minimize the time between seed sowing and seedling emergence and to ensure synchronize emergence Parera and Cantliffe [10]. These effects of priming are collaborated with repairing and building up of nucleic acids, increased synthesis of proteins as well as the repairing of membranes McDonald 
[11]. Priming also enhances the activities of anti-oxidative enzymes in treated seeds Hsu et al. [12] and Wang et al. [13]. Seed priming can be carried out using different techniques viz. hydro-priming (soaking in distilled water), osmopriming (soaking in osmotic solutions such as PEG, potassium salts, e.g., $\mathrm{KCl}, \mathrm{K}_{2} \mathrm{SO}_{4}$ ) and plant growth inducers (CCC, Ethephon, IAA) Chiu et al. [14], Capron et al. [15] Harris et al. [16] and Chivasa et al. [17]. Under osmopriming (also addressed as osmoconditioning) the seeds are drenched into synthetic compound like: polyethylene glycol (PEG), sorbitol, mannitol solution and let to uptake water to primary metabolic activities of germination process is started, and radical emergence occurred Ashraf and Foolad [9]. Osmopriming in the PEG solution allows initiating the membrane repairing systems and metabolic preparation for germination via controlling the water absorption rate of seeds Jisha et al. [18]. This technique is frequently used in some countries for vegetables and flower crops Halmer [19]. Past studies were evident that PEG had no toxic effect since all seeds germinated. Mehra et al. [20] reported that PEG molecules do not enter to seed and there was no toxicity of PEG. According to McDonald [11], primed seeds acquire the potentiality to rapidly imbibe and revive the seed metabolism thus enhancing the germination rate. Osmopriming and hydropriming of wheat seeds may improve germination and emergence Ashraf and Abu-Shakra [21] and may promote proliferous and vigorous root growth Carceller and Soriano [22]. Moreover, priming increases the activities of glyoxysome enzymes in primed bitter gourd seeds Lin and Sung [23]. Baque et al. [24] reported that $10 \%$ PEG was best for enhanced germination behavior of wheat. In many crops, germination and early seedling growth are the most sensitive stages of water deficit and the water deficit may delay the onset and decrease the rate and uniformity of germination, leading to reduced crop performance and yield Demir et al. [25]. Therefore, the beneficial effects of priming may be more evident under unfavorable rather than favorable conditions Parera and Cantliffe [10]. These phenomena have empirical agronomic inference especially under adverse germination state. McDonald [11]. Therefore, the study was carried out to find suitable priming agent(s) for seed industry that might be used to enhance the tolerance capability of plants under adverse field conditions for successful crop production in different regions especially salt and drought-prone areas in Bangladesh.

\section{Materials and Methods}

The experiment was carried out in the Central Laboratory of the Department of Agronomy, Sher-e-Bangla Agricultural University, Dhaka October, 2016. The temperature and relative humidity were $26^{\circ} \mathrm{C}-33^{\circ} \mathrm{C}$ and $55-85 \%$, respectively during the experimentation period. Four wheat genotypes namelyBARI Gom 28, ESWYT-5, ESWYT -6 and ESWYT-7, screened out under salinity stress condition Hasan [26] were used for this experiment and were collected from seed technology division of Bangladesh Agricultural Research Institute were used as planting material. PEG and distilled water were used as Osmo and hydro priming agent, respectively in this study. To fulfill the study, growth chamber, electric balance, petri dish, filter paper, micropipette etc. equipments were used.

$5 \mathrm{~g}$ of PEG was dissolved in $100 \mathrm{ml}$ of water to prepare $5 \%$ solution of PEG. Similarly, 10g, 15g, 20g PEG was dissolved in $100 \mathrm{ml}$ of water to make $10 \%, 15 \%, 20 \%$ solution of PEG, respectively.

Seeds of wheat genotypes were sterilized using 2\% Safex solution for 5 minutes, rinsed those seeds using distilled water and air dried at room temperature. Then the seeds were ready for priming treatment.

The priming media were formulated using distilled water and the soaking duration was $12 \mathrm{~h}$ for osmo and hydropriming treatment. After incubation into primed solution seeds were air dried and placed in the petri dish. For each replicate, 30 seeds were placed in $12.5 \mathrm{~cm}$ petri dish on a layer of filter paper no. 102 which was previously moistened with $8 \mathrm{ml}$ distilled water.

The experiment was carried out following Completely Randomized Design (CRD) with five replications. The wheat genotypes were examined under six priming conditions (distilled water and 5\%, 10\%, 15\%, 20\% PEGs solution). Seeds without priming used as control. After that data collected on various parameters such as mean data of germination percentage, shoot length, root length, shoot dry weight, root dry weight, relative water content, water saturation deficit, water retention capacity, germination coefficient and vigor index were recorded.

Germination was recorded one day after placing seeds for germination and continued up to eleven day with an interval of $24 \mathrm{hr}$. More than $2 \mathrm{~mm}$ long plumule and radicle seed was considered as germinated seed.

The germination rate was calculated using following formula:

Germination percentage (\%) = TotalNumberofgerminatedseeds Totalseedplacedforgermination Germination percentage $(\%)=\frac{\text { Total } \mathrm{Numberofgerminatedseeds}}{\text { Totalseedplacedforgermination }} \times 100$

Germination Co- efficient (GC) was calculated using the following formula Copeland [27]:

$$
\text { Germination Co- efficient }(\%)=\frac{A 1+A 2+\cdots+A x}{A 1 T 1+A 2 T 2+\cdots A x T x} \times 100
$$


Where,

$$
\begin{gathered}
A=\text { Number of seeds germinated } \\
T=\text { Time corresponding to } A \\
x=\text { Number of days to final count }
\end{gathered}
$$

Vigour index was calculated using following formula Abdul-Baki and Anderson [28]:

$$
\text { Vigour index }=\frac{\text { Totalgermination } \times \text { Seedlinglength }(\mathrm{mm})}{100}
$$

At the eleventh day five seedlings of each petri dish were sampled. Shoot and root length of single seedling was measured with meter scale. Then the shoot and root of the seedling were dried for $48 \mathrm{hr}$ then dry weight of shoot and root were recorded using electric balance.

After recording the fresh weight leaf of each seedling place into ptridish for $24 \mathrm{hr}$ then leaf soaking with distilled water turgid weight was recorded when it was dried for 48 $\mathrm{hr}$ the dry weight was measured.

Relative water content was measured using following formula Baque et al. [29]:

$$
\begin{gathered}
\text { Relative water content }(\text { WRC })(\%)= \\
\frac{\text { Freshweight }- \text { Dryweight }}{\text { Tugidweight }- \text { Dryweight }} \times 100
\end{gathered}
$$

Water saturation deficit was recorded using following formula Baque et al. [29]:

Water saturation deficit $(\mathrm{WSD})=100$ - Relative water content

Water retention capacity was measured following formula Baque et al. [29]:

$$
\text { Water retention capacity }(\text { WTC })=\frac{\text { Turgidweight }}{\text { Dryweight }}
$$

\section{Statistical Analysis}

The data of the study were analyzed statistically following CRD design by MSTAT-C analysis software and the mean separation was done using Least Significance Differences (LSD) test at $1 \%$ level of probability.

\section{Result and Discussion}

\subsection{Germination Percentage}

Germination percentage of wheat genotypes significantly is influenced by different PEG solutions (Line graph 1). Hydro and osmo priming solutions affected the germination percentage of wheat genotypes. Germination percentage (GP) increases with the increasing of PEG concentration up to $10 \%$ then there was a gradual decrease observed with increasing the PEG concentration. The result of the experiment revealed that the maximum germination percentage $(95.30 \%)$ was recorded from wheat genotype ESWYT-5 $\left(\mathrm{V}_{1}\right)$ with 10\% PEG solution and the minimum germination percentage $(65.90 \%)$ was recorded from wheat genotype ESWYT-7 $\quad\left(\mathrm{V}_{4}\right)$ with $0 \%$ PEG concentration (control). Among the wheat genotypes ESWYT-5 $\left(\mathrm{V}_{1}\right)$ performed best, and ESWYT-7 $\left(\mathrm{V}_{4}\right)$ performed the poor performance and rest of the two genotypes showed moderately in most of the PEG concentrations. The result of the experiment collaborated with the results of Baque et al. [24], Yagmur and Kaydan [30], Kaya et al. [31], Afzal [32] Afzal et al. [33], Basra et al. [34], Demir and Ermis [35] and Roy and Srivastava [36]. Basra et al. [24] and Salinas [37] reported refinement in germination percent, emergence and seedling standby using seed priming techniques.

A wide range of biochemical changes occurred during seed priming which was crucial for germination, i.e., breaking of dormancy, hydrolysis or metabolism of inhibitors, imbibitions and enzymes activation Ajouri et al. [38]. Researcher demonstrated that the priming process that antedate the germination is boosted by priming and preserved following the re-desiccation of the seed Asgedom and Becker [39]. Primed seed can rapidly consume and resuscitate the seed metabolism, as a result germination percentage was increased and the physiological heterogeneity was triggered down Rowse [40]. Moreover, seed priming most likely grants some fix-up of damage to membrane caused by deterioration and resulted in better germination pattern and higher vigor level compared with non-primed seeds Jisha et al. [18] and Ruan et al. [41]. Priming showed reviving effects in the early stages of germination by the mediation of cell division in germinating seeds Hassanpouraghdam et al. [42]. Similar mechanisms seem to perform in the course of our experiments so that PEG-primed seeds resulted in higher germination attributes and rapid seedling growth under osmotic stress. Hydropriming significantly boost germination rate Ghassemi-Golezani et al. [43] and is a useful technique for optimized overall germination Maiti et al. [44] and these beneficial effects of hydropriming have been attributed to the mobilization in embryonic tissues of enzyme activities required for rapid seed germination and of compounds such as free amino acids, proteins, and soluble sugars from storage organs Ashraf and Foolad [9]. Farooq et al. [45] proposed that physiological changes exerted by osmohardening increased the starch hydrolysis and made more sugars available for embryo growth which enhances germination. Baque et al. [24] reported that $10 \%$ PEG was best for improved germination behavior of wheat. The report of the Sun et al. [46] revealed the compatible PEG concentration were 20\% for Gangyou 527 (indica hybrid rice) and 10\%-15\% for Nongken 57 (conventional japonica rice). During germination, PEG concentration above the optimum level had adverse effects. Singh and Gill [47] reported that over-priming $\left(\mathrm{KNO}_{3}\right)$ might be appeared toxic to primed seed due to prolonged soaking in primed solution $\left(\mathrm{KNO}_{3}\right)$ that might have injured the cellular organelles. 


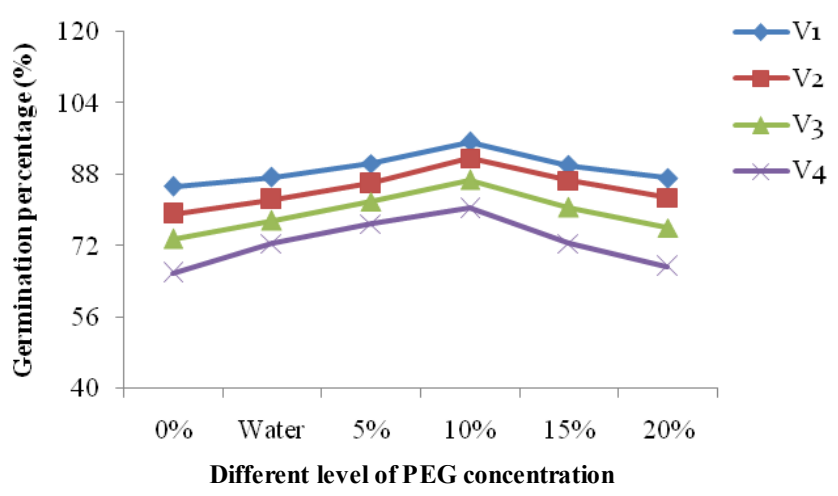

Line graph 1. Effect of various concentrations of Polyethylene Glycol (PEG) on the germination percentage of wheat genotypes LDS $_{(0.01)}=$ $6.92,4.59,7.88,5.89,7.19$ and 6.39 at $0 \%$, water, $5 \%, 10 \%, 15 \%$ and $20 \%$ PEG concentrations, respectively); $\mathrm{V}_{1}=\mathrm{ESWYT}-5, \mathrm{~V}_{2}=\mathrm{ESWYT}-6, \mathrm{~V}_{3}=$ BARI Gom 28 and $\mathrm{V}_{4}=$ ESWYT -7

\subsection{Shoot Length}

Shoot length of wheat genotypes significantly affected by different PEG solutions (Line graph 2). Shoot length of wheat genotype increased with the increasing of PEG concentration up to $10 \%$, and there was a gradual decreased observed with increasing the PEG concentration. The result of the experiment revealed that the maximum shoot length $(168.20 \mathrm{~mm})$ was recorded from wheat genotype ESWYT-5 $\left(\mathrm{V}_{1}\right)$ with $10 \%$ PEG concentration whereas the minimum shoot length $(108.20 \mathrm{~mm})$ was recorded from wheat genotype ESWYT-7 $\left(\mathrm{V}_{4}\right)$ with control treatment ( non-primed seed). Wheat genotype ESWYT-6 $\left(\mathrm{V}_{2}\right)$ performed similar with ESWYT-5 $\left(\mathrm{V}_{1}\right)$ under most of the PEG concentrations but ESWYT-7 $\left(\mathrm{V}_{4}\right)$ poorly performed under all the osmo and hydro priming solutions. This result is in agreement with the findings of several workers Baque et al. [24], Jisha et al [18] and Maiti et al. [11]. Rennick and Tiernan [48] reported that there was a rapid and more extended elongation of coleoptile occurred in treated seeds than non-treated and over primed seeds. Lee and Kim [49] revealed that, priming increased the metabolic activities of seed ultimately gained the substantial shoot length than nonprimed seed. Baque et al. [24] reported that the highest shoot length of wheat was secured when the seed primed with $10 \%$ PEG solution.

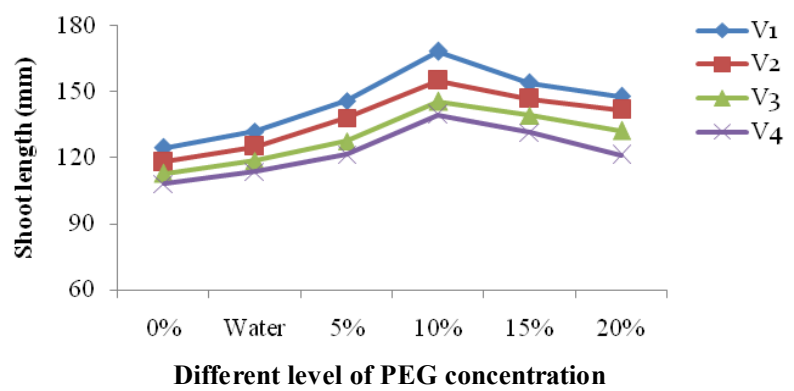

Line graph 2. Effect of various concentrations of Polyethylene Glycol (PEG) on the shoot length of wheat genotypes $\left(\operatorname{LDS}_{(0.01)}=10.54,9.37\right.$, $13.53,11.62,11.68$ and 11.20 at $0 \%$, water, $5 \%, 10 \%, 15 \%$ and $20 \%$ PEG concentrations, respectively); $\mathrm{V}_{1}=\mathrm{ESWYT}-5, \mathrm{~V}_{2}=\mathrm{ESWYT}-6, \mathrm{~V}_{3}=\mathrm{BARI}$ Gom 28 and $\mathrm{V}_{4}=$ ESWYT-7

\subsection{Root Length}

Root length of wheat genotypes significantly varied by different PEG solutions (Line graph 3). Root length of wheat genotype increased with the increasing of PEG concentration up to $10 \%$ and there was a gradual decreased with increasing the PEG concentration. The result of the experiment revealed that the maximum root length $(158.30$ $\mathrm{mm})$ was scored by ESWYT-5 $\left(\mathrm{V}_{1}\right)$ with $10 \%$ PEG concentration whereas the minimum root length (98.46 $\mathrm{mm})$ was recorded from ESWYT-7 $\left(\mathrm{V}_{4}\right)$ with control treatment (non-primed seed). Wheat genotype ESWYT-5 $\left(\mathrm{V}_{1}\right)$ performed the best, ESWYT-6 $\left(\mathrm{V}_{2}\right)$ and BARI Gom $28\left(\mathrm{~V}_{3}\right)$ gave intermediate results but ESWYT-7 $\left(\mathrm{V}_{4}\right)$ consistently poor performance under all the osmo and hydro priming solutions. This result is in agreement with the findings of several workers Baque et al.[24], Jisha et al. [18] and Maiti et al. [11]. Experiments conducted by Ashraf and Abu-shakra [21] revealed that priming of wheat seed in osmoticum or water might improve germination and emergence and aggrandize vigorous root growth Carceller and Soriano [22] as a consequence root length of osmo and hydro primed seed exerted the highest length than non-primed seed. The considerable root length in the treated seeds might be due to increased metabolic activities in the primed seeds than non-primed Baque et al. [24] and Lee and Kim [23]. Jisha et al. [18] reported that overall growth of plants was enhanced due to the seed-priming treatments. Maiti et al. [44] observed that seed priming the seedling vigor of several vegetable crops. The priming techniques improved seedling growth of tomato and chili. Baque et al. [24] concluded that the most extended root length was recorded when the seed primed with $10 \%$ PEG solution.

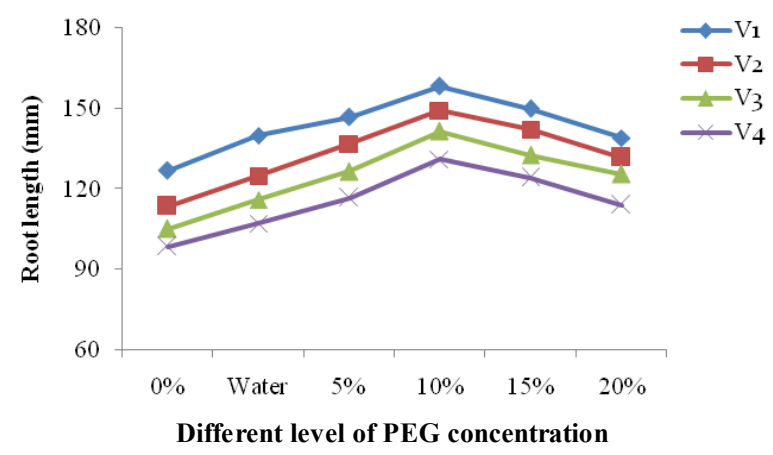

Line graph 3. Effect of various concentrations of Polyethylene Glycol (PEG) on the root length of wheat genotypes $\left(\operatorname{LDS}_{(0.01)}=9.36,10.78,9.84\right.$, $12.45,12.77$ and 13.35 at $0 \%$, water, $5 \%, 10 \%, 15 \%$ and $20 \%$ PEG concentrations, respectively); $\mathrm{V}_{1}=$ ESWYT $-5, \mathrm{~V}_{2}=$ ESWYT-6, $\mathrm{V}_{3}=$ BARI Gom 28 and $\mathrm{V}_{4}=$ ESWYT -7

\subsection{Shoot Dry Weight}

The result of the experiment revealed that the highest shoot dry weight $(0.052 \mathrm{mg})$ was scored by ESWYT-5 $\left(\mathrm{V}_{1}\right)$ with $10 \%$ PEG concentration whereas the minimum shoot 
dry weight $(0.021 \mathrm{mg})$ was recorded from wheat genotype ESWYT-7 $\left(\mathrm{V}_{4}\right)$ with 0\% PEG solutions (non-primed seed) (Line graph 4). The result of the present study was also supported by the result of previous researchers Baque et al. [24], Khalil et al. [50], Ghassemi-Golezani et al. [43] and Sarwar et al. [51]. Priming presumably permitted some repairs of damaged to membrane caused by deterioration and exerted better germination pattern and higher vigor level than non- primed Ruan et al. [41]. Nascimento and West [52] mentioned minimizing of seed coat adherence during the emergence of muskmelon seeds. The refinement in germination and vigor of standard/low-vigor seed might be due to preserve transportation of food material, trigger and re-synthesis of some enzymes, DNA and RNA synthesis start during osmotic priming. Removing of obstacle speed up the germination of seed ultimately produced the vigorous shoot and increased shoot dry weight of wheat genotypes Basra et al. [4]. Khalil et al. [50] observed that dry matter yield increased with each increment of priming. Ghassemi-Golezani et al. [43] showed that hydro-priming significantly improved shoot weights and Sarwar et al. [51] reported that shoot length and biomass of shoots were better when treated with water and mannitol. Baque et al. [24] found that maximum shoot dry weight was recorded when the seed primed with $10 \%$ PEG solution compared to that of osmo and hydro primed seed.

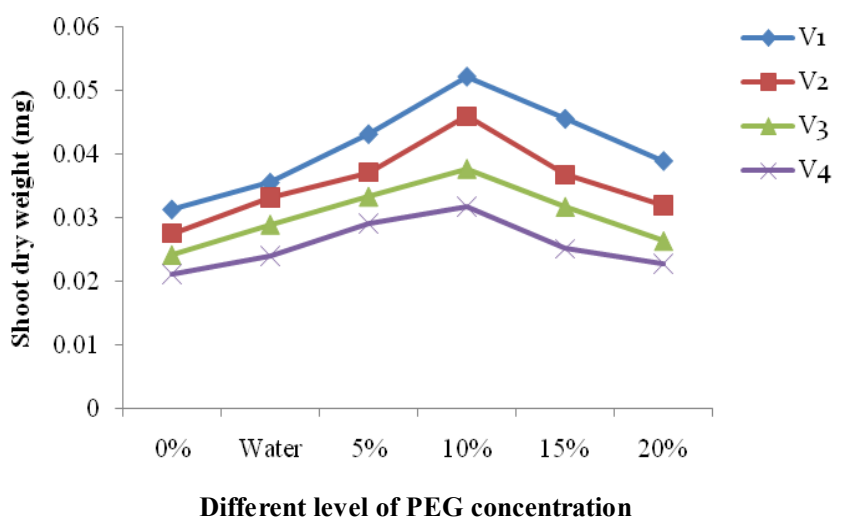

Line graph 4. Effect of various concentrations of Polyethylene Glycol $(\mathrm{PEG})$ on the shoot dry weight of wheat genotypes $\left(\mathrm{LDS}_{(0.01)}=0.01,0.01\right.$, $0.01,0.01,0.01$ and 0.01 at $0 \%$, water, $5 \%, 10 \%, 15 \%$ and $20 \%$ PEG concentrations, respectively); $\mathrm{V}_{1}=$ ESWYT $-5, \mathrm{~V}_{2}=$ ESWYT $-6, \mathrm{~V}_{3}=$ BARI Gom 28 and $\mathrm{V}_{4}=$ ESWYT-7

\subsection{Root Dry Weight}

In case of root dry weight ESWYT-5 $\left(\mathrm{V}_{1}\right)$ consistently scored the highest value and ESWYT-7 $\left(\mathrm{V}_{4}\right)$ scored the lowest value under most of the priming treatments. The result of the experiment revealed that the highest root dry weight $(0.043 \mathrm{mg})$ was observed in ESWYT-5 $\left(\mathrm{V}_{1}\right)$ with $10 \%$ PEG concentration whereas the minimum root dry weight $(0.015 \mathrm{mg})$ was recorded in ESWYT-7 $\left(\mathrm{V}_{4}\right)$ with control treatment (non-primed seed) (Line graph 5). The result of the present study is also in line with the results of previous researchers Baque et al. [24], Khalil et al. [50], Ghassemi-Golezani et al. [43] and Sarwar et al. [51]. Khalil et al. [50] observed that dry matter yield increased with each increment of priming. Ghassemi-Golezani et al. [43] showed that hydro-priming significantly improved root weights and Sarwar et al. [51] reported that root length and biomass of roots were better when treated with water and mannitol. Baque et al. [24] found that maximum root dry weight was recorded when the seed primed with $10 \%$ PEG solution.

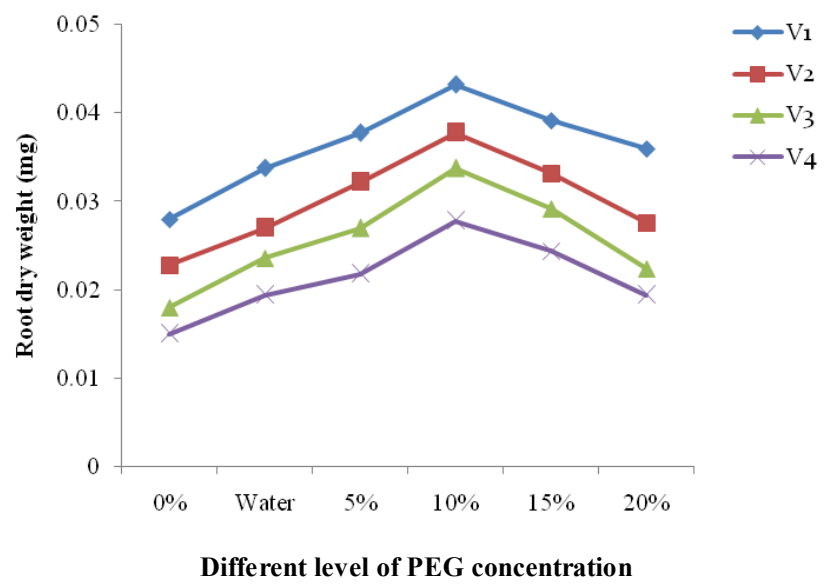

Line graph 5. Effect of various concentrations of Polyethylene Glycol (PEG) on the root dry weight of wheat genotypes $\left(\operatorname{LDS}_{(0.01)}=0.01,0.01\right.$, $0.01,0.01,0.01$ and 0.01 at $0 \%$, water, $5 \%, 10 \%, 15 \%$ and $20 \%$ PEG concentrations, respectively); $\mathrm{V}_{1}=\mathrm{ESWYT}-5, \mathrm{~V}_{2}=\mathrm{ESWYT}-6, \mathrm{~V}_{3}=\mathrm{BARI}$ Gom 28 and $\mathrm{V}_{4}=$ ESWYT -7

\subsection{Relative Water Content}

RWC could be the perfect indicator of plant hydrologic condition as it denotes the physiological consequences of cellular water deficit. Water potential that possess the energy status of plant water which is useful for the transportation of water in the soil-plant-atmosphere chain. A wide range of statistical difference was observed for the relative water content of wheat genotypes under different PEG solutions (Line graph 6). Corresponding water content followed the similar trend as the previous parameters of wheat genotypes. The result revealed that the maximum relative water content $(90.05 \%)$ was found from ESWYT-5 $\left(\mathrm{V}_{1}\right)$ under 10\% PEG concentration and the minimum relative water content $(61.63 \%)$ was found from ESWYT-7 $\left(\mathrm{V}_{4}\right)$ with 0\% PEG concentration. ESWYT-5 $\left(\mathrm{V}_{1}\right)$ performed distinctly superior to ESWYT-7 $\left(\mathrm{V}_{4}\right)$ where ESWYT-6 $\left(\mathrm{V}_{2}\right)$ and BARI Gom $28\left(\mathrm{~V}_{3}\right)$ gave the intermediate results under all the osmo and hydro priming solutions. Under stress condition, osmo and hydro primed seedling can thrive and provide better water use efficiency thus plant growth not hampered than non-primed seeds Flower et al. [53]. A similar finding was reported by Sairam et al. [54]. 


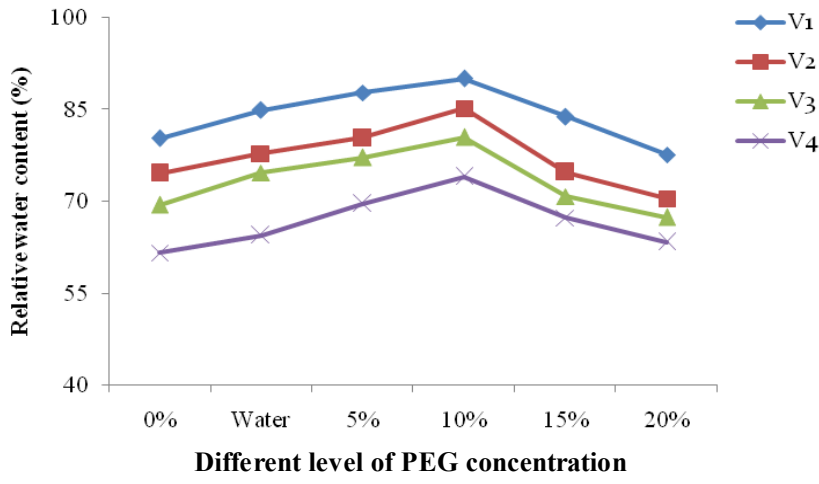

Line graph 6. Effect of various concentrations of Polyethylene Glycol $(\mathrm{PEG})$ on the relative water content of wheat genotypes $\left(\operatorname{LDS}_{(0.01)}=5.66\right.$, $6.52,4.76,7.04,4.16,5.27$ at $0 \%$, water, 5\%, 10\%, 15\% and $20 \%$ PEG concentrations, respectively); $\mathrm{V}_{1}=\mathrm{ESWYT}-5, \mathrm{~V}_{2}=\mathrm{ESWYT}-6, \mathrm{~V}_{3}=\mathrm{BARI}$ Gom 28 and $\mathrm{V}_{4}=$ ESWYT-7

\subsection{Water Saturation Deficit}

Water saturation deficit of wheat genotypes influenced significantly by different PEG solutions (Line graph 7). It followed the opposite trend compared to the previously described parameter, i.e., the water saturation deficit was maximum at $0 \%$ PEG concentration and gradually decreased up to $10 \%$ PEG concentration and then steadily increased. ESWYT-7 $\left(\mathrm{V}_{4}\right)$ performed poor under all the PEG concentrations and scored the highest value distinctly under all the priming solution where ESWYT-5 $\left(\mathrm{V}_{1}\right)$ consistently scored the minimum value for water saturation deficit under all osmo and hydro priming solutions. The highest water saturation deficit (38.37) was recorded from ESWYT-7 $\left(\mathrm{V}_{4}\right)$ with 0\% PEG solution and the lowest (9.95) were recorded from ESWYT-5 $\left(\mathrm{V}_{1}\right)$ with $10 \%$ PEG solution. Due to lack of defense mechanism, the non-primed seedling failed to uptake enough water necessary for running the physiological process smoothly than the primed seedling. Thus there was a massive water deficit occurred in case of non-primed genotypes than the primed genotypes. A similar result was reported by Baque et al. [29].

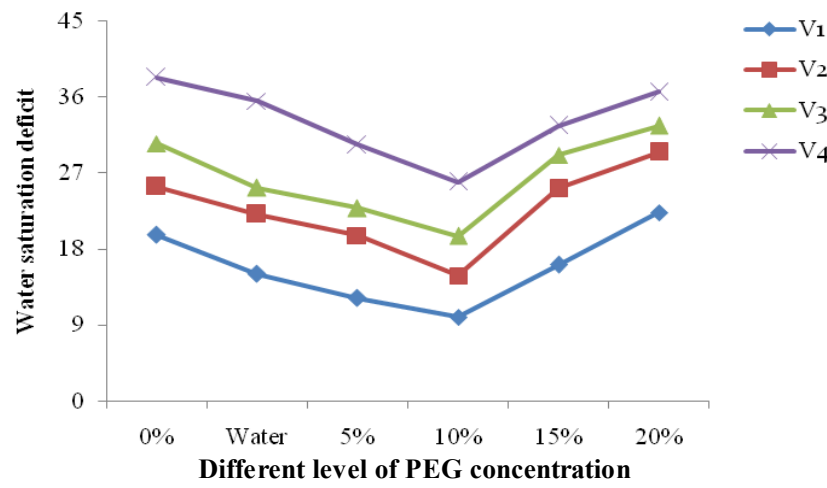

Line graph 7. Effect of various concentrations of Polyethylene Glycol (PEG) on the water saturation deficit of wheat genotypes $\operatorname{LDS}_{(0.01)}=2.56$, $1.80,1.68,1.21,2.46$ and 2.64 at $0 \%$, water, $5 \%, 10 \%, 15 \%$ and $20 \%$ PEG concentrations, respectively); $\mathrm{V}_{1}=\mathrm{ESWYT}-5, \mathrm{~V}_{2}=\mathrm{ESWYT}-6, \mathrm{~V}_{3}=$ BARI Gom 28 and $\mathrm{V}_{4}=$ ESWYT-7

\subsection{Water Retention Capacity}

Water retention capacity of wheat genotypes influenced significantly by different PEG solutions (Line graph 8). ESWYT-5 $\left(\mathrm{V}_{1}\right)$ wheat genotype distinctly scored the highest value for water retention capacity under most of the osmo and hydro priming solutions where ESWYT-7 $\left(\mathrm{V}_{4}\right)$ consistently showed the poor performance. Result revealed that the maximum water retention capacity (17.50) was scored by ESWYT-5 $\left(\mathrm{V}_{1}\right)$ with 10\% PEG solution while the minimum value (10.62) scored by ESWYT-7 $\left(\mathrm{V}_{4}\right)$ with $0 \%$ PEG solutions. As priming helps to activate the metabolic enzymes responsible for germination of seed before germination takes place, so the hydro and osmo primed seedlings can uptake more water than the non-primed ones and gained the maximum turgid weight, in consequence, they gained the maximum water retention capacity.

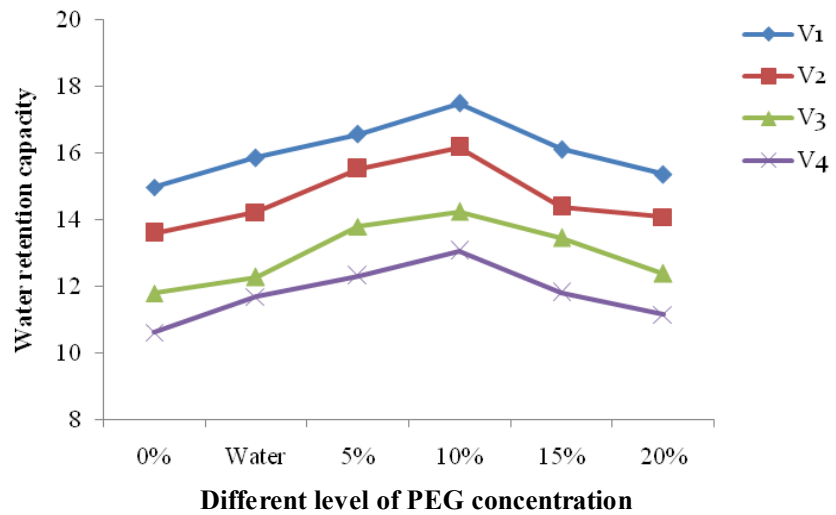

Line graph 8. Effect of various concentrations of Polyethylene Glycol (PEG) on the water retention capacity of wheat genotypes LDS $_{(0.01)}=$ $0.97,1.16,1.33,1.28,1.25$ and 1.25 at $0 \%$, water, $5 \%, 10 \%, 15 \%$ and $20 \%$ PEG concentrations, respectively); $\mathrm{V}_{1}=$ ESWYT $-5, \mathrm{~V}_{2}=$ ESWYT- $6, \mathrm{~V}_{3}=$ BARI Gom 28 and $\mathrm{V}_{4}=$ ESWYT -7

\subsection{Germination Coefficient}

Different Polyethylene Glycol (PEG) solutions significantly influenced the germination coefficient of wheat genotypes except under 15 and 20\% (Line graph 9). The maximum germination coefficient (16.90) was recorded from ESWYT-5 $\left(\mathrm{V}_{1}\right)$ when the seed primed with $10 \%$ PEG concentration whereas the minimum germination coefficient (12.55) was recorded from ESWYT-7 $\left(\mathrm{V}_{4}\right)$ when the seed was not primed with osmo or hydro priming solutions. ESWYT-6 showed similarity with ESWYT-5 under all the priming solutions. This result was in line with the findings of Baque et al. [24] and Huns and Sung [55] who reported that seed priming resulted from anti-oxidant increment as glutathione and ascorbate in the seed. These enzymes trigger germination speed via reduction of lipid peroxidation activity; as a result germination coefficient was higher in osmo and hydro primed seed compare to that of non-primed seeds. Baque et al. [24] reported that the highest germination coefficient 
was recorded when the seed primed with $10 \%$ PEG solution compared to that of osmo and hydro primed seed. Osmopriming of Italian ryegrass (Lolium multiflorum) and sorghum (Sorghum bicolor) seeds with 20\% PEG- 8000 for $2 \mathrm{~d}$ at $10^{\circ} \mathrm{C}$ enhanced germination coefficient of wheat genotypes under water stress, waterlogging, cold stress and saline conditions Hur [56]. It has been evident that priming had resulted in more germination speed especially in salt and drought stress, saline stress and low temperatures in sorghum, sunflower, and melon Kaya et al. [31], Sivritepe et al. [57] and Foti et al. [58].

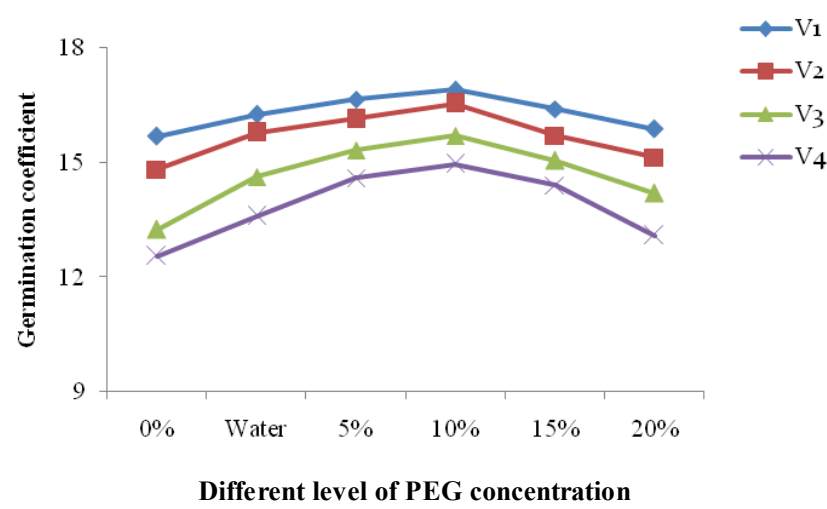

Line graph 9. Effect of various concentrations of Polyethylene Glycol (PEG) on the germination coefficient of wheat genotypes LDS $_{(0.01)}=$ $1.17,1.07,0.62,0.85,0.82$ and 0.86 at $0 \%$, water, $5 \%, 10 \%, 15 \%$ and $20 \%$ PEG concentrations, respectively); $\mathrm{V}_{1}=\mathrm{ESWYT}-5, \mathrm{~V}_{2}=\mathrm{ESWYT}-6, \mathrm{~V}_{3}=$ BARI Gom 28 and $\mathrm{V}_{4}=$ ESWYT -7

\subsection{Vigor Index}

Line graph 10 showed that, the maximum vigor index (311.30) was accounted from wheat genotype ESWYT-5 $\left(\mathrm{V}_{1}\right)$ when the seed primed with $10 \%$ PEG solution and minimum vigor index (136.20) was achieved from ESWYT-7 $\left(\mathrm{V}_{4}\right)$ when the seeds were not primed either osmo or hydro priming solutions. In case of vigor index, ESWYT-5 distinctly scored the highest value under all the osmo and hydro priming solutions whereas ESWYT-7 consistently performed poor and ESWYT-6 and BARI Gom 28 scored intermediate value. This result was also in agreement with the findings of Baque et al. [24], Maiti et al. [59] and Maiti et al. [44] who reported that seed priming increases the seedling vigor of several vegetable crops and concerning sponge gourd, osmo-priming increased seedling vigor. Nascimento and West [52] mentioned that, the minimization of seed coat adherence during the emergence of muskmelon seeds after priming. The advancement in germination and vigor of soybean plant was probably due to the reserve mobilization of food material, activation and re-synthesis of some enzymes, DNA and RNA synthesis started during osmotic priming Sadeghi et al. [60]. There might be the possibility that similar germination responsive genes may be activated because of chitosan priming under osmotic stress. Baque et al. [24] found that maximum vigor index was recorded when the seed primed with 10\% PEG solution. Osmopriming of Italian ryegrass (Lolium multiflorum) and sorghum (Sorghum bicolor) seeds with 20\% PEG-8000 for $2 \mathrm{~d}$ at $10^{\circ} \mathrm{C}$ increased the vigor index.

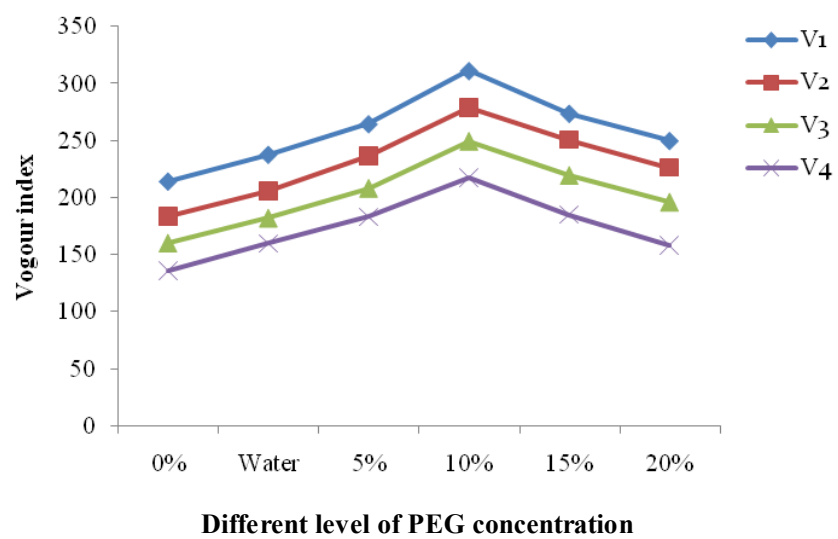

Line graph 10. Effect of various concentrations of Polyethylene Glycol $(\mathrm{PEG})$ on the vigour index of wheat genotypes $\left(\operatorname{LDS}_{(0.01)}=13.38,17.31\right.$, $23.62,23.76,24.61$ and 17.18 at $0 \%$, water, $5 \%, 10 \%, 15 \%$ and $20 \%$ PEG concentrations, respectively); $\mathrm{V}_{1}=$ ESWYT $-5, \mathrm{~V}_{2}=\mathrm{ESWYT}-6, \mathrm{~V}_{3}=\mathrm{BARI}$ Gom 28 and $\mathrm{V}_{4}=$ ESWYT -7

\section{Conclusions}

Considering the above results obtaining from the present piece of work it may be concluded that PEG has a positive effect on germination, seedling growth and water relation behavior on wheat seed. Among four wheat genotypes, ESWYT-5 wheat genotypes were performed best in most of the germination, seedling growth and water relation behavior of wheat where wheat genotypes ESWYT-6 and BARI Gom 28 showed moderate results and ESWYT-7 showed consistently poor performance. All the parameters of wheat genotypes gave the best results when seeds treated with $10 \%$ PEG solution compared to nonprimed and hydro primed seeds and the recorded results decreased gradually with increasing PEG concentration. So, it can be concluded that seed treated with Polyethylene Glycol (PEG) helps to increase the germination, seedling growth and water relation on wheat genotypes.

\section{Acknowledgements}

This research work was fully financed by BAS-USDA, PALS, project no. CR-09, Bangladesh Academy of Science, National Science and Technology Museum Bhaban, Agargaon, Dhaka-1207, Bangladesh.

\section{REFERENCES}

[1] WHEAT. Wheat: vital grain of civilization and food security 
2013 Annual Report, CGIAR Research Program on Wheat, Mexico, 2014.

[2] M. Quamruzzaman, M. J. Ullah, M. J. Rahman, R. Chakraborty, M. M. Rahman and M. G. Rasul. Organoleptic assessment of Groundnut (Arachishypogaea L.) as influenced by boron and artificial lightening at night. World J. Agric. Sci. 12(1): 01-06, 2016.

[3] G. J. M. Beckers and U. Conrath. Priming for stress resistance: from the lab to the field. Curr. Opin. Plant Biol. 10: 425-431, 2007.

[4] S. M. A. Basra, M. Farooq and R. Tabassum. Physiological and biochemical aspects of seed vigour enhancement treatments in fine rice (Oryza sativa L.). Seed Sci. Technol. 33: 623-628, 2005.

[5] D. J. Cantliffe. Seed Enhancements. J. Acta Horticulturae. 607: 53-59, 2003.

[6] A. A. Powell, L. J. Yule, H. C. Jingh and P. C. Groots. The influence of aerated hydration seed treatment on seed longevity as assessed by the viability equation. J. Exp. Bot. 51: 2031-2043, 2000.

[7] A. G. Taylor, P. S. Allen, M. A. Bennett, K. J. Bradford, J. S. Burris and M. K. Misra. Seed enhancements. J. Seed Sci. Res. 8: 245-256, 1998.

[8] F. Carbineau and D. Come. Priming: a technique for improving seed quality. J. Seed Testing Int. p. 132, 2006.

[9] M. Ashraf and M. R. Foolad. Pre-sowing seed treatment a shotgun approach to improve germination, plant growth, and crop yield under saline and non-saline conditions. J. Adv. Agron. 88: 223-271, 2005.

[10] C. A. Parera and D. J. Cantliffe. Pre-sowing seed priming. J. Hort. Rev. 16: 109-141, 1994.

[11] M. B. McDonald. Seed priming, Black, M., J. D. Bewley, (Eds.), Seed Technology and Its Biological Basis, Sheffield Academic Press, Sheffield, UK. pp. 287-325, 2000.

[12] C. C. Hsu, C. L. Chen, J. J. Chen and J. M. Sung. Accelerated aging-enhanced lipid peroxidation in bitter gourd seeds and effects of priming and hot water soaking treatments. J. Sci. Hort. 98: 201-212, 2003.

[13] H. Y. Wang, C. L. Chen and J. M. Sung. Both warm water soaking and solid priming treatments enhance anti-oxidation of bitter gourd seeds germinated at sub-optimal temperature. J. Seed Sci. Technol. 31: 47-56, 2003.

[14] K. Y. Chiu, C. L. Chen and J. M. Sung. Effect of priming temperature on storability of primed sh-2 sweet corn seed. Crop Sci. 42: 1996-2003, 2002.

[15] I. Capron, F. Corbineua, F. Dacher, C. Job, D. Come and D. Job. Sugar beet seed priming: Effects of priming conditions on germination, solubilization of 11-s globulin and accumulation of LEA proteins. Seed Sci. Res. 10: 243-254, 2000 .

[16] D. Harris, A. Joshi, P. A. Khan, P. Gothakar and P. S. Sodhi. On-farm seed priming in semi-arid agriculture: Development and evaluation in corn, rice and Chickpea in India using participatory method. Expt. Agric. 35: 15-29, 1999.
[17] W. Chivasa, D. Harris, C. Chiduza and P. Nymudeza. Agronomic practices, major crops and farmer's perceptions of good stand establishment in musikavanhu. J. Appl. Sci. 4: 109-125, 1998.

[18] K. C. Jisha, K. Vijayakumari and J. T. Puthur. Seed priming for abiotic stress tolerance: an overview. Acta. Physiol. Plant. 35(5): 1381-1396, 2013.

[19] P. Halmer. Methods to improve seed performance in the field. Handbook of Seed Physiology, Applications to Agriculture. pp. 125-165, 2004.

[20] V. Mehra, J. Tripathi and A. A. Powell. Aerated hydration treatment improves the response of Brassica juncea and Brassica campestris seeds to stress during germination. Seed Sci. Technol. 31: 57-70, 2003.

[21] Ashraf, M., and Abu-Shakra, S. (1978). Wheat seed germination under low temperature and moisture stress. $J$. Agron. 70: 135 - 139.

[22] M. S. Carceller and A. Soriano. Effect of treatments given to grain, on the growth of wheat roots under drought conditions. Canadian J. Bot. 50: 105-108, 1972.

[23] J. M. Lin and J. M. Sung. Pre-sowing treatments for improving emergence of bitter gourd seedlings under optimal and sub-optimal temperatures. J. Seed Sci. Technol. 29: $39-50,2001$

[24] A. Baque, M. Nahar, M. Yeasmin, M. Quamruzzaman, A Rahman, M. J. Azad and P. K. Biswas. Germination behavior of wheat (Triticum aestivum L.) as influenced by polyethylene glycol (PEG). Universal J. Agril. Res. 4(3): 86-91, 2016.

[25] A. O. Demir, A. T. Goksoy, H. Buyukcangaz, Z. M. Turan and E. S. Koksal. Deficit irrigation of sunflower (Helianthus annuus L.) in a sub-humid climate. Irrig. Sci. 24: 279-289.

[26] M. M. Hasan, M. A. Baque, M. A. Habib, M. Yeasmin and M. A. Hakim. Screening of salt tolerance capability of wheat genotypes under salt stress condition. Universal J. Agril. Res. 5(4): 235-249, 2017.

[27] L. Copeland. Principle of Seed Science and Technology. Burgess Publishing Company, Minneapolis, Mannishly. pp. 164-165, 1976.

[28] A. A. Abdul-Baki and J. D. Anderson. Viability and leaching of sugars from germinating barley. Crop Sci. 10: 31-34, 1970 .

[29] M. A. Baque, M. A. Karim and A. Hamida. Role of potassium on water relation behavior of Triticum astivum $\mathrm{L}$. under water stress conditions. Prog. Agric. 13(1\&2): 71-75, 2002.

[30] M. Yagmur and D. Kaydan. Alleviation of osmotic stress of water and salt in germination and seedling growth of triticale with seed priming treatments. African J. Biotechnol. 7: 2156-2162, 2008.

[31] M. D. Kaya, O. Gamze, M. Atal, C. Yakup and K. Ozer. Seed treatments to overcome salt and drought stress during germination in sunflower (Helianthus annuus L.). European J. Agron. 24: 291-295, 2006. 
[32] I. Afzal. Seed enhancements to induced salt tolerance in wheat (Triticum aestivum L.), Ph.D. Thesis, Agricultural University of Faisalabad, Pakistan, 2005.

[33] I. S. Afzal, M. A. Basra and A. Iqbal. The effects of seed soaking with plant growth regulators on seedling vigour of wheat under salinity stress. J. Stress Physiol. Biochem. 1: $6-14,2005$

[34] S. M. A. Basra, E. E. Ullah, A. Warriach, M. A. Cheema and I. Afzal. Effect of storage on growth and yield of primed canola seeds (Brassica napus). Int. J. Agric. Biol. 5: 117-120, 2003.

[35] I. Demir and S. Ermis. Effect of controlled hydration treatment on germination and seedling growth under salt stress during development in tomato seeds. European J. Hor. Sci. 68: 53-58, 2003.

[36] N. K. Roy and A. K Srivastava. Adverse effect of salt stress conditions on chlorophyll content in wheat (Triticum aestivum $\mathrm{L}$.) leaves and its amelioration through pre-soaking treatments. Indian J. Agric. Sci. 70: 777-778, 2000.

[37] A. R. Salinas. Influence of Glycine $\max$ (L.) Merrill seed quality on crop establishing and overcoming of ambient stress. Pesquisa Agropecuaria Brasileira. 31: 379-386, 1996.

[38] A. Ajouri, A. Haben and M. Becker. Seed priming enhances germination and seedling growth of barley under conditions of P and Zn deficiency. J. Plant Nutri. Soil Sci. 167: 630-636, 2004.

[39] H. Asgedom and M. Becker. Effects of seed priming with nutrient solutions on germination, seedling growth and weed competitiveness of cereals in Eritrea. In: Proc. Deutscher Tropentag, University of Bonn and ATSAF, Magrraf Publishers Press, Weickersheim. p. 282, 2001.

[40] H. R. Rowse. Drum Priming- A non-osmotic method of priming seeds. Seed Sci. Technol. 24: 281-294, 1995.

[41] S. Ruan, Q. Xue and K. Tylkowska. The influence of priming on germination of rice Oryza sativa L. seeds and seedling emergence and performance in flooded soil. Seed Sci. Technol. 30: 61-67, 2002.

[42] M. B. Hassanpouraghdam, P. J. Emarat and A. N. Farsad. The effect of osmo-priming on germination and seedling growth of Brassica napus L. under salinity conditions. J. Food Agric. Environ. 7(2): 620-622, 2009.

[43] K. Ghassemi-Golezani, A. A. Aliloo, M. Valizadeh and M. Moghaddam. Effects of hydro and osmo-priming on seed germination and field emergence of lentil (Lens culinaris Medik.). Not. Bot. Hort. Agrobot. Cluj. 36(1): 29-33, 2008.

[44] R. Maiti, D. Rajkumar, M. Jagan and K. Pramanik. Effect of seed priming on seedling vigour and yield of tomato and chilli. Int. J. Bio-res. Stress Manag. 4(2): 119-125, 2013.

[45] M. Farooq, S. M. A. Barsa and A. Wahid. Priming of field-sown rice seed enhances germination, seedling establishment, allometry and yield. Plant Growth Regul. 49(2): 285-294, 2006.

[46] Y. Sun, Y. Sun, M. Wang, X. Li, X. Guo and R. Hu. Effects of seed priming on germination and seedling growth under water stress in rice. Acta Agronomica Sinica. 36(11): 1931-1940, 2010.

[47] H. Singh and H. S. Gill. Effect of Seed treatment with slats on germination and yield of wheat. Agric. Sci. Digest. 8(4): 173-175, 1988.

[48] G. A. Rennick and P. I. Tiernan. Some effects of osmopriming on germination, growth and yield of celery (Apium graveolens). Seed Sci. Technol. 6: 695-700, 1978.

[49] S. S. Lee and J. H. Kim. Total sugars, $\alpha$-amylase activity and germination after priming of normal and aged rice seeds. Korean J. Crop Sci. 45: 108-111, 2000.

[50] S. K. Khalil, S. Khan, A. Rahman, A. Z. Khan, I. H. Khalil, W. S. Amanullah, F. Mohammad, S. Nigar, M. Zubair, S. Parveen and A. Khan (2010). Seed priming and phosphorus application enhance phenology and dry matter production of wheat. Pakistan J. Bot. 42(3): 1849-1856, 2010.

[51] N. Sarwar, S. Yousaf and F. Jamil. Induction of salt tolerance in chickpea by using simple and safe chemicals. Pakistan J. Bot. 38(2): 325-329, 2006.

[52] W. M. Nascimento and S. H. West. Priming and Seed Orientation affect emergence and seed coat adherence and seedling development of muskmelon transplants. Hort. Sci. 33: 847-848, 1998.

[53] T. J. Flower, F. M. Salma and A. R. Yeo. Water use efficiency in rice in relation to plant. Plant cell Environ. 11: 453-459, 1998.

[54] R. K. Sairam, R. K. Veerabhadra and G. C. Srivastava Differential response of wheat genotypes to long term salinity stress in relation to oxidative stress, antioxidant activity and osmolyte concentration. Plant Sci. 163: 1037-1046, 2002.

[55] Y. H. Huns and J. M. Sung. Biochemical activities associated with priming of sweet corn seeds to improve vigor. Seed Sci. Technol. 21: 97-105, 1997.

[56] S. N. Hur. Effect of osmoconditioning on the productivity of Italian ryegrass and sorghum under suboptimal conditions. Korean J. Anim. Sci. 33: 101-105, 1991.

[57] N. Sivritepe, H. O. Sivritepe and A. Eris. The effects of $\mathrm{NaCl}$ priming on salt tolerance in melon seedling grown under saline conditions. Scientia Holticuturae. 97: 229-237, 2003.

[58] S. Foti, S. L. Cosentino, C. Patane and G. M. D'Agosta. Effect of osmoconditioning upon seed germination of Sorghum (Sorghom bicolor L) under low temperatures. Seed Sci. Technol. 30: 521-533, 2002.

[59] R. K. Maiti, P. Vidyasagar, D. Rajkumar, A. Ramaswamy and H. G. Rodriguez. Seed Priming improves seedling vigor and yield of few vegetable crops. Int. J. Bio-res. Stress Manag. 2(1): 125-130, 2011.

[60] H. Sadeghi, F. Khazaei, L. Yari and S. Sheidaei. Effect of seed osmopriming on seed germination behavior and vigor of soybean (Glycine max L.). J. Agric. Biol. Sci. 6(1): 39-43, 2011 . 